Eixo Roda, Belo Horizonte, v. 29, n. 4 p. 171-187, 2020

\title{
As vozes nas marginálias de Fantoches: roupagens verbais e imagéticas de Erico Verissimo
}

\author{
The Voices in the Marginalias of Fantoches: \\ Verbal and Imagectic Clothing by Erico Verissimo
}

\author{
Airton Pott \\ Universidade de Passo Fundo (UPF), Passo Fundo, Rio Grande do Sul / Brasil \\ airton_pott@yahoo.com.br \\ https://orcid.org/0000-0002-9809-1320 \\ Miguel Rettenmaier da Silva \\ Universidade de Passo Fundo (UPF), Passo Fundo, Rio Grande do Sul / Brasil \\ mrettenmaier@hotmail.com
}

https://orcid.org/0000-0002-8523-3270

Resumo: Autor de uma gama de obras, sobretudo romances e demais narrativas, Erico Verissimo não se abstém da criatividade na hora da escrita. O que também pode surpreender alguns de seus leitores é o hábito que possuía de fazer registros não verbais, tais como caricaturas de suas personagens e demais representações imagéticas relacionadas às suas obras. A edição de Fantoches (1972), que comemora o quadragésimo aniversário da publicação de estreia desse livro, o primeiro do autor, é um propício exemplo disso. Sendo assim, esta obra, formada por uma série de pequenas narrativas, muitas delas peças teatrais, fornece o corpus para os estudos aqui propostos, já que se pretende analisar os registros manuscritos, tanto verbais quanto não verbais, feitos pelo próprio autor e que confirmam a crítica dele mesmo com relação às suas próprias produções. Para tanto, as análises fundamentam-se nos estudos de crítica literária de Bordini (1995), bem como sobre teorias a respeito dos recursos verbais e não verbais, de Ackerman (2014) e Aurouet (2014), utilizando-se também o primeiro volume de Solo de Clarineta: Memórias (2005), também de Verissimo. Autocrítico como é, Erico Verissimo permite fazer inferências sobre o fato de que uma obra publicada não significa que não existe a possibilidade de acrescências posteriores, o que na edição analisada de Fantoches permite muitas percepções a respeito das diferentes vozes encontradas também nas marginálias do livro, acrescidas pelo autor por meio de desenhos e observações verbais.

Palavras-chave: Fantoches; marginálias; vozes; Erico Verissimo. 
Abstract: Author of a range of works, especially novels and other narratives, Erico Verissimo does not abstain from creativity at the time of writing. What may also surprise some of his readers is his habit of making non-verbal records, such as caricatures of his characters and other imagistic representations related to his works. The edition of Fantoches (1972), which commemorates the 40th anniversary of the publication of this book, which was his first, is a fitting example of this. Thus, this work, formed by a series of small narratives, many of them plays, provides the corpus for the studies proposed here, since it is intended to analyze the verbal and non-verbal manuscript records made by the author himself and confirm his own criticism of his own productions. To that end, the analyses are based on Bordini's (1995) studies of literary criticism, as well as on verbal and nonverbal theories by Ackerman (2014) and Aurouet (2014), and the first volume of the book Solo de Clarineta: Memórias (2005), also by Verissimo. Self-critical as he is, Erico Verissimo allows us to make inferences about the fact that the publication of a work does not mean that there is no possibility of later additions, which in the analyzed edition of Fantoches (1972) leaves room for many perceptions regarding the different voices also found in the marginalia of the book, added by the author through drawings and verbal observations.

Keywords: Fantoches; marginalias; voices; Erico Verissimo.

\section{Considerações iniciais}

Muitos dos estudos de crítica genética levam em conta os manuscritos da obra antes de ela ser publicada. No entanto, com a edição que homenageia os quarenta anos de Fantoches o inverso é concebível, já que o próprio autor da obra faz considerações verbais e não verbais ao longo dos textos do livro, republicado quatro décadas depois.

Fantoches (1972) é um livro composto por narrativas, muitas delas peças de teatro, e foi o livro de estreia de Erico Verissimo, reconhecido como um dos grandes nomes da literatura prosaica brasileira. Já na epígrafe, bem como em outros elementos pré-textuais, o autor faz fac-símiles manuscritos, o que se sucede ao longo de toda a obra.

Graças aos registros verbais e imagéticos, feitos por esse escritor em uma das edições anteriores desse livro, foi possível publicar uma nova edição com essas narrativas e os manuscritos de Erico Verissimo. Muitas dessas informações, feitas à mão, mostram a habilidade de desenhar de Verissimo, já que ele gostava de materializar os personagens, e não apenas imaginá-los.

O livro Fantoches (1972) apresenta o material de análise. No entanto, os estudos de crítica literária de Bordini (1995) subsidiam tanto a fundamentação teórica quanto as análises dos manuscritos selecionados. 
Ackerman (2014) e Auroeut (2014) fornecem aparato teórico voltado a produções relacionadas a recursos verbais e não verbais. Recorre-se também ao primeiro volume do livro Solo de Clarineta: Memórias (2005), do mesmo autor de Fantoches, já que, nele, Verissimo conta sobre suas obras, suas inspirações e motivações para escrever suas narrativas e livros, dentre os quais está aquele selecionado para análise neste artigo.

Dessa forma, torna-se pertinente realizar verificações sobre as considerações manuscritas nas marginálias de Fantoches (1972) a fim de coletar informações sobre as opiniões construtivas do próprio autor, bem como suas influências, sua personalidade e suas observações sobre as suas produções literárias dentro do livro. Se Erico Verissimo lançou desnudos seus personagens ao mundo, mais tarde volta para vesti-los por meio das marginálias.

\section{Considerações sobre manuscritos verbais e não verbais}

Se "o livro também é vida substituta e, como tal, sempre lhe falta algo, que de novo criador pode tentar suprir" (BORDINI, 1995, p. 64), pode-se afirmar que um livro nunca está completo, acabado. Logo, tem-se a possibilidade de acrescentar algo às lacunas, aos lugares vazios, onde pode estar o inesperado por detrás da colina, ou seja, além das palavras ali estáticas. No entanto, esses acréscimos, quando feitos, não precisam necessariamente ser por meio de palavras, podendo, inclusive, ser por elementos não verbais.

Diante do fato de a imagem ser "um terreno de experimentação para diferentes variantes" (ACKERMAN, 2014, p. 64), salienta-se que ela é uma opção diferente de representação, percepção ou complementação de um texto. Assim, torna-se uma maneira inteligível de repassar informações ao outro, ao leitor.

Ademais, há uma relação de sentido preestabelecida entre a imagem e a escrita, seja esta a escrita manuscrita feita junto ao desenho, ou aquela pertencente ao texto já publicado. Segundo Ackerman (2014, p. 65), "essa correspondência entre desenho e plano convida a investigar a função semântica dos detalhes dessa cena". Portanto, tem-se nessas relações um material que pode contribuir para diferentes percepções, como complementações e acréscimos de informações sobre a história narrada, sobre o autor, e/ou acontecimentos reais; enfim, múltiplas opções de informações além das perpassadas apenas por meio da linguagem verbal. 
Independentemente das finalidades das imagens e anotações acrescidas às margens de Fantoches (1972), obra de Erico Verissimo que foi selecionada como corpus dos estudos aqui realizados, enfatiza-se que "na maioria das vezes, os desenhos servem verdadeiramente aos propósitos do autor e trazem dados suplementares de tal forma que a imagem está em perfeita simbiose com o verbo, pois o ilustra e o enriquece" (AUROEUT, 2014, p. 43).

Já que era do feitio de Erico Verissimo fazer desenhos representativos de suas obras e personagens, a mescla do imagético com o verbal não é só um meio de acrescentar informações, mas também uma realização prazerosa do autor. Dessa forma, "não se poderia atribuir uma mera função decorativa aos objetos de arte" (ACKERMAN, 2014, p. 65). Tanto as imagens quanto as palavras acrescidas pelo autor nas margens do livro contêm informações que complementam os textos escritos décadas antes.

Em vista disso, o desenho pode representar palavras, conseguindo transmitir informações parecidas com aquelas possíveis por meio da linguagem verbal. Conforme Ackerman (2014, p. 64),

O desenho pode, assim, bruscamente substituir o escrito, interrompendo o processo literário para dar lugar à atividade gráfica. Essa complementaridade dos suportes incita ainda mais a abordar os desenhos preparatórios recorrendo-se aos métodos da genética literária dos manuscritos.

Ao fazer considerações sobre o roteiro de um filme de Prévert, Auroeut (2014, p. 44), afirma que "do visual ao verbal para redundar em imagens animadas, tal é o caminho seguido pela obra". No entanto, o caminho percorrido por Erico Verissimo em Fantoches (1972) é um pouco diferente, pois o autor parte de uma edição desta obra publicada em 1932 e vai às ilustrações verbais e visuais encontradas na versão posterior, o que, por razões de composição e publicação, difere daquilo que Prévert realiza em seu filme. Isso por razões óbvias, pois este faz os desenhos a fim de ajudar nas cenas e nas gravações. Já Verissimo pode fazer seus manuscritos nas marginálias por inúmeras e (des)conhecidas razões, posteriormente à primeira edição do livro.

Além do mais, como os desenhos de Erico Verissimo na edição de 40 anos de Fantoches são posteriores à edição de 1932, eles não são preparatórios para a obra, mas sim mediadores de ressignificações e atualizações. Assim, muitos deles podem servir para representar algo importante que o autor quis enfatizar, ou que ele queria imaginar, já que 
era típico dele desenhar as personagens para elas não ficarem apenas na imaginação. No entanto, as concepções arroladas ao fato de o desenho ser um suporte para uma ideia coincidem com o desenho preparatório abordado e considerado por Ackerman (2014, p. 67):

O caso mais frequente do desenho preparatório parece ser o do desenho como suporte para uma ideia. De fato, certos desenhos não correspondem a um plano particular, mas expressam o tema geral ligado ao elemento representado. $\mathrm{O}$ desenho serve, nesses casos, para memorizar a ideia principal de uma cena.

Mediante a percepção de que os desenhos também são expressões do tema é verossímil ressaltar que "atribuir ao fato uma dimensão simbólica lhe acrescenta credibilidade" (AUROEUT, 2014, p. 35). A partir disso, assevera-se que as ilustrações escritas e imagéticas não são contrárias às narrativas escritas e publicadas. Pelo contrário, os manuscritos e desenhos são uma complementaridade do texto publicado, podendo ser ainda uma continuidade, pois, dessa forma, são adicionadas informações à obra.

Com seus estudos voltados a considerações e análises sobre desenhos em filmes, Ackerman (2014, p. 68) vai ratificar que "de maneira geral, o estudo dos desenhos permite captar muitas sutilezas que não são, necessariamente, percebidas quando se assiste ao filme." Contudo, perante o fato de isso não ocorrer apenas no processo relacionado a filmes, mas também a livros e demais textos, pode-se afirmar que o mesmo ocorre com os manuscritos e as imagens em Fantoches (1972), uma vez que elas podem representar inúmeras palavras escritas e informações implícitas intencionadas pelo autor.

Bordini (1995), ao realizar estudos de crítica literária nas obras de Erico Verissimo, afirma que há elementos rituais constantes que vêm ao encontro da função dos desenhos, o que demonstra seu ato criativo. Ainda segundo ela, "Erico deixa claro que o processo criativo se inicia pela concepção da personagem, não da ação ou do cenário, e através de uma visualização esquemática de sua figura" (BORDINI, 1995, p. 69).

Nessa perspectiva, os desenhos de Verissimo nas marginálias de Fantoches (1972) podem ser relacionados à concepção de rascunho de Auroeut (2014, p. 34): "o rascunho não constitui uma verdadeira primeira etapa, na medida em que o original não está no verbo, mas na documentação prévia e no imaginário." Trata-se do caso dos manuscritos de Fantoches, publicados na edição de 1972, posteriores à primeira publicação, e não 
prévios, como a ideia de um rascunho. A teoria do rascunho é válida, mas remete, nesse caso, a uma etapa posterior à publicação, a qual não é final, necessariamente, já que "se o romance está acabado, a arte toda também está e haveria o retorno ao caos" (BORDINI, 1995, p. 47). Deste modo, uma obra é inacabada, incompleta, ou seja, é possível acrescentar informações a ela.

Além disso, ainda a partir da afirmação de Auroeut (2014), asseverase que a percepção do verbal e do imaginário também é cabível, uma vez que é o imaginário do autor que permitiu escrever tais narrativas, bem como fazer as ilustrações e considerações escritas posteriormente nas margens do próprio livro. Como em Fantoches (1972) são muitas as ilustrações manuscritas verbais ou não verbais enfatiza-se que elas têm múltiplas e distintas finalidades. A respeito disso, vale acentuar que

O desenho funciona igualmente como um storyboard para cenas específicas. Enquanto certos desenhos poderiam constituir desenhos autônomos, por seu grafismo ser suficientemente eloquente, outros funcionam apenas como notas de trabalho, seja evidenciando um detalhe, seja acompanhados de anotações. (ACKERMAN, 2014, p. 66).

Em vista a muitas possíveis finalidades dos desenhos e manuscritos verbais a respeito da obra, pode-se inferir que os mesmos representam o elíptico ou o inconsciente do autor, pois "o enfoque principal de Erico quanto à criação é o trabalho do inconsciente" (BORDINI, 1995, p. 62). Nessa perspectiva, se essa afirmação for combinada às marginálias de Fantoches, talvez os manuscritos de Verissimo, tanto verbais quanto imagéticos, visem instigar o leitor e o próprio autor sobre os elementos ali representados. Deste modo,

O indivíduo, seja ele produtor ou receptor de um texto artístico, pode escolher livremente entre possibilidades distintas de atribuição de sentido e também criar para si novas possibilidades ainda não existentes, mesmo que todo esse processo esteja sobredeterminado pela ideologia, no plano social, e pelo inconsciente, no plano individual. (BORDINI, 1995, p. 22).

Em linhas gerais, faz-se sobressair que os estudos dos manuscritos verbais e imagéticos são possíveis graças à crítica genética. Além disso, eles permitem enxergar além da colina, ou seja, além do que já está escrito, publicado. Afinal, um livro, assim como uma colina, pode ocultar belezas inestimáveis, e também profundos espinhos, perdições. E para desvendar tais mistérios é preciso ir além do que está visível e selecionar os elementos com os quais se vai menear. Por ora, é essencial saber da existência das 
roupagens em Fantoches (1972), que é possível acrescer costuras a elas e o que as já existentes representam.

\section{Fantoches, candidato eleito: elucubrações sobre a obra e seu autor}

A edição de Fantoches de 1972 é guardadora de vários registros verbais e não verbais feitos pelo próprio autor do livro ao longo de suas marginálias. Erico Verissimo faz várias observações ao longo da obra, que é republicada com seus manuscritos feitos nas margens relacionados à própria obra e aos diferentes momentos de sua carreira de escritor. Muitas dessas observações são feitas de forma criativa e humorística. Já com relação ao título da obra, o autor faz suas ressalvas, muitas descontraídas, que também evidenciam sobre o processo de criação pelo qual o autor passa.

Vários eram os possíveis títulos cogitados por Erico Verissimo para seu livro composto por vários textos de cunho narrativo. Dentre os candidatos ao título da primeira obra publicada por esse escritor, Fantoches foi o eleito, conforme evidenciado pelas ilustrações do próprio autor em um dos elementos pré-textuais encontrados na edição publicada em 1972, que integra o corpus dessa pesquisa:

FIGURA 1 - Manuscritos do autor sobre o título da obra

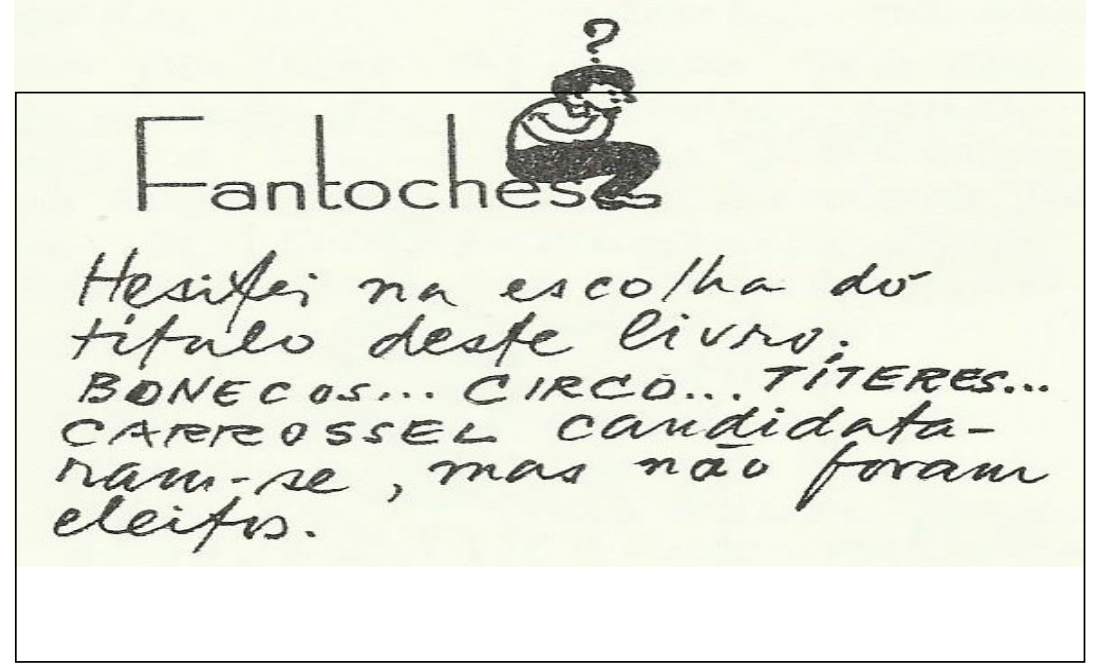

Fonte: Verissimo, 1972, p. 2. 
A partir dessa ilustração é perceptível a ideia de dúvida, reforçada com o ponto de interrogação acima da cabeça do sujeito encurvado, o que também é característica do ser pensante, já representado na escultura $O$ pensador (1904), do francês Auguste Rodin. Essa incógnita na ilustração de Verissimo marca o fato de o autor se colocar em dúvida, inclusive no que concerne à palavra a empregar, possivelmente pelo sentido semântico individual de cada uma delas. A preocupação da seleção dos vocábulos, para Erico, torna-se imprescindível porque ele tem consciência de que

O expressado, então, deixa de pertencer a seu sujeito, assim como o que se comunica pode ser apropriado e desviado por quem recebe a comunicação, de modo que todo o processo ao mesmo tempo pode ser e não ser o que dele se desejava, num verdadeiro jogo de sombras ou ilusões, em que a figura do fantoche se impõe. (BORDINI, 1995, p. 197).

Desse modo, o leitor tem papel fundamental não só nas obras de Erico Verissimo, mas em todas as obras produzidas, pois é ele quem se torna o sujeito atuante, receptor do texto, e pode ou não gostar do que leu ou está lendo. Diante disso, o leitor depende do autor para ler algo, assim como o autor precisa do leitor para que haja alguém que leia suas produções. Erico Verissimo tem plena consciência disso e de críticas, tanto favoráveis quanto contrárias, assim como o processo de influências e experiências prévias, pois em suas memórias autobiográficas ele evidencia, a respeito da obra Fantoches, que:

Fantoches apareceu assim em 1932 - uma coleção de contos em sua maioria na forma de pequenas peças de teatro, com influências de Ibsen, Shaw, Anatole France e Pirandello [...]. Agripino Grieco, crítico iconoclasta, implacável demolidor de figurões literários, mas juiz indulgente dos principiantes, tratou meu primogênito com grande simpatia, o que muito me incentivou. Amigos escreveram notas favoráveis sobre os meus bonecos. É natural que houvesse também críticas desfavoráveis ou apenas neutras. (VERISSIMO, 2005, p. 234).

Independentemente de críticas e infortúnios ocorridos, como o incêndio do armazém onde estavam os volumes ainda não vendidos de Fantoches, Erico Verissimo tornou-se alguém conhecido nacional e internacionalmente, sobretudo com obras futuras, principalmente a trilogia de O tempo e o vento. Nestas obras, explora temáticas distintas de Fantoches, já que neste "buscava-se ver a substância artificial da ficção que se nutre de um conhecimento livresco da vida" (BORDINI, 1995, p. 218). 
No entanto, Verissimo, com o costume de avaliar suas obras ao marginá-las, percebe que a temática da sua criação literária primogênita pode ter sido um fator que não contribuiu para seu sucesso inicial. Afinal, o público leitor poderia não concordar ou não se interessar pela sua arte diegética, suas irrealidades criadas em Fantoches. Bordini (1995) vai ressaltar que os temas dessa obra permeiam entre a arbitrariedade e a autonomia da ficção, o poder ilusório da arte.

Em virtude disso, acentua-se que os leitores não embarcaram no mundo ficcional, imaginário e aventuroso de Verissimo. No entanto, como bom autor, ele percebe a necessidade que tem de se adaptar ao público, fato que faz com que suas obras posteriores a sua primeira tenham um público invejável a muitos. Além disso, também Fantoches é uma obra visitada e revisitada não apenas pelo seu próprio criador, mas também por outros leitores e, assim, é atualizada e modificada por cada receptor conforme a realização de uma nova leitura.

\section{0 verbal e o imagético nas marginálias de Fantoches}

Ao escrever um texto ficcional é natural que o autor se isole da realidade e mergulhe no mundo da imaginação. Para Erico Verissimo tal prática não era incomum, pois conforme ele mesmo afirma no seu livro de memórias Solo de Clarineta, ele "vivia mais no mundo da imaginação que no da realidade" (VERISSIMO, 2005, p. 56). Muito desse fenômeno permitia que ele viajasse para o mundo imaginário e trouxesse parte disso para a realidade. Como, por exemplo, o fato de que Erico Verissimo, seu irmão e seus amigos brincavam de D'Artagnan e os três mosqueteiros, inspirados na obra de Alexandre Dumas, Os três mosqueteiros, conforme ele mesmo escreve em suas memórias:

A França nos mandava filmes de aventuras que nada ficavam a dever aos italianos, como, por exemplo, Os três mosqueteiros. D'Artagnan passou a ser um menino que vivia à sombra duma nespereira, com uma espada de pau à cinta, na cabeça um chapéu de palha ornamentado com penas arrancadas a um velho espanador. Meu irmão, o mais alto do grupo, passou a ser o Porthos. Estêvão, o sábio, era o Athos. Faute de mieux, Pitoco encarnou Aramis. Todos havíamos jurado defender a rainha contra as trampas do cardeal e seus cumpinhas. (VERISSIMO, 2005, p. 116).

Essa brincadeira de infância é, de certa forma, rememorada em Nanquinote, uma das narrativas encontradas no livro Fantoches (1972). 
Não obstante, nesta história, eles têm apenas uma rápida aparição, conforme pode ser averiguado na figura a seguir:

FIGURA 2 - Desenho e escrita a partir do texto

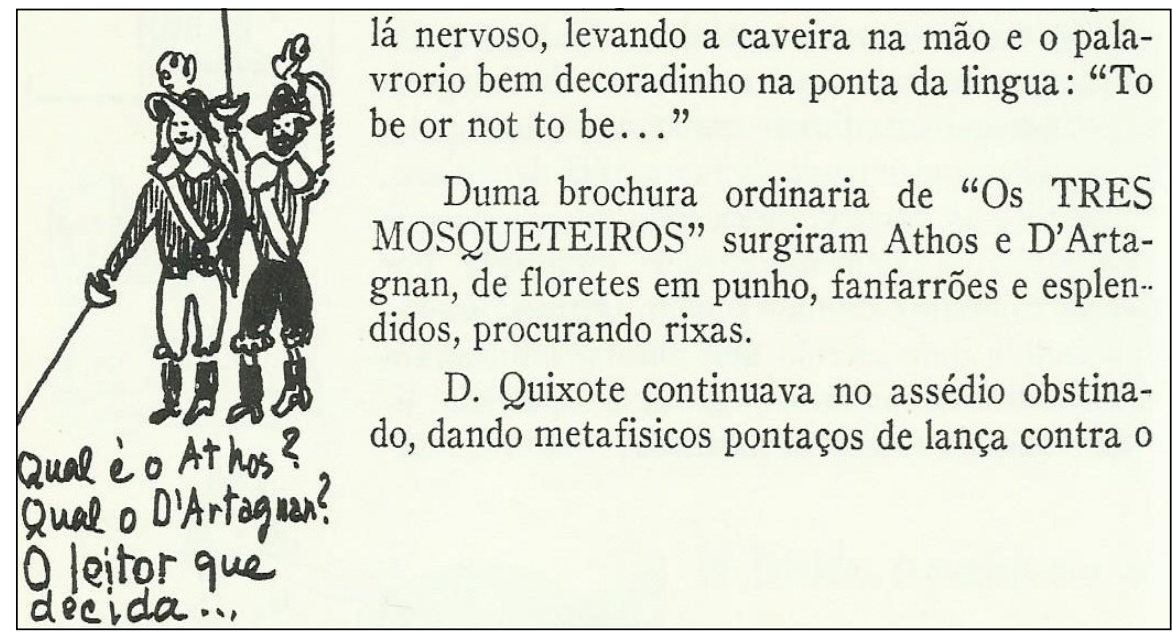

Fonte: Verissimo, 1972, p. 186.

No entanto, o fato de ser praticamente apenas uma menção da obra na narrativa, publicada inicialmente em 1932, não impediu que esse fragmento ganhasse notabilidade do próprio autor quando este revisitou a obra, fazendo complementações verbais e imagéticas ao longo dela, inclusive desse trecho. Por isso tudo, salienta-se que essa ilustração nas marginálias do livro possivelmente foi motivada pela brincadeira de infância de Erico Verissimo, o que é reforçado não apenas pelos desenhos representativos de Athos e D'Artagnan, mas também pelas indagações “Qual é o Athos? Qual o D'Artagnan?”. Além disso, lança ao leitor decidir quem é quem dos dois. Afinal, depois do texto pronto, na prática da leitura, o leitor torna-se sujeito ativo e passa a tomar decisões sobre muitas coisas que o autor deixou sob forma de lacunas a serem preenchidas, o que coincide com o fato de um texto nunca estar completo.

Esses arrazoados nas marginálias de Fantoches (1972), assim como tantas outras desse livro, mostram que Erico Verissimo fez muitas criações inspiradas em suas próprias experiências de vida. Contudo, depois, em outro momento, após a primeira publicação do livro, revisita a obra e acrescenta-lhe informações. Essa rememoração é registrada pelo próprio 
autor através de uma quantia não escassa de complementações, amostragens e esclarecimentos.

Logo, ao considerar tais manuscritos de Erico Verissimo, é incabível, nesses casos, o fato de que "a estrutura parece estar plasmada na sua mente de tal forma que nem sente mais necessidade de desenhá-la para criar" (AUROEUT, 2014, p. 40). Independentemente de necessidade ou não, Verissimo faz desenhos pelo simples fato de que ele acaba gostando de suas personagens e, portanto, as desenha, veste-as com informações e complementos. Ele gosta tanto delas que as representa imageticamente a fim de que possa marginá-las não somente por intermédio das palavras, mas marginá-las de sua mente.

Sendo assim, Verissimo quer ver suas criações, independentemente do fato de saber ou não no imaginário como elas são. Isso é facilmente perceptível nas faces e na postura das representações caricaturais de seus personagens, como em uma pestanejada, em um sorriso, sem se preocupar com a qualidade do desenho, uma vez que este não é um dos principais propósitos do autor, prevalecendo, portanto, a importância do conteúdo. Enfim, as feições e expressões corporais de muitos desenhos de Verissimo ilustram e mostram muito bem isso, como, por exemplo, na figura a seguir:

FIGURA 3 - Desenho representativo de expressões faciais e corporais

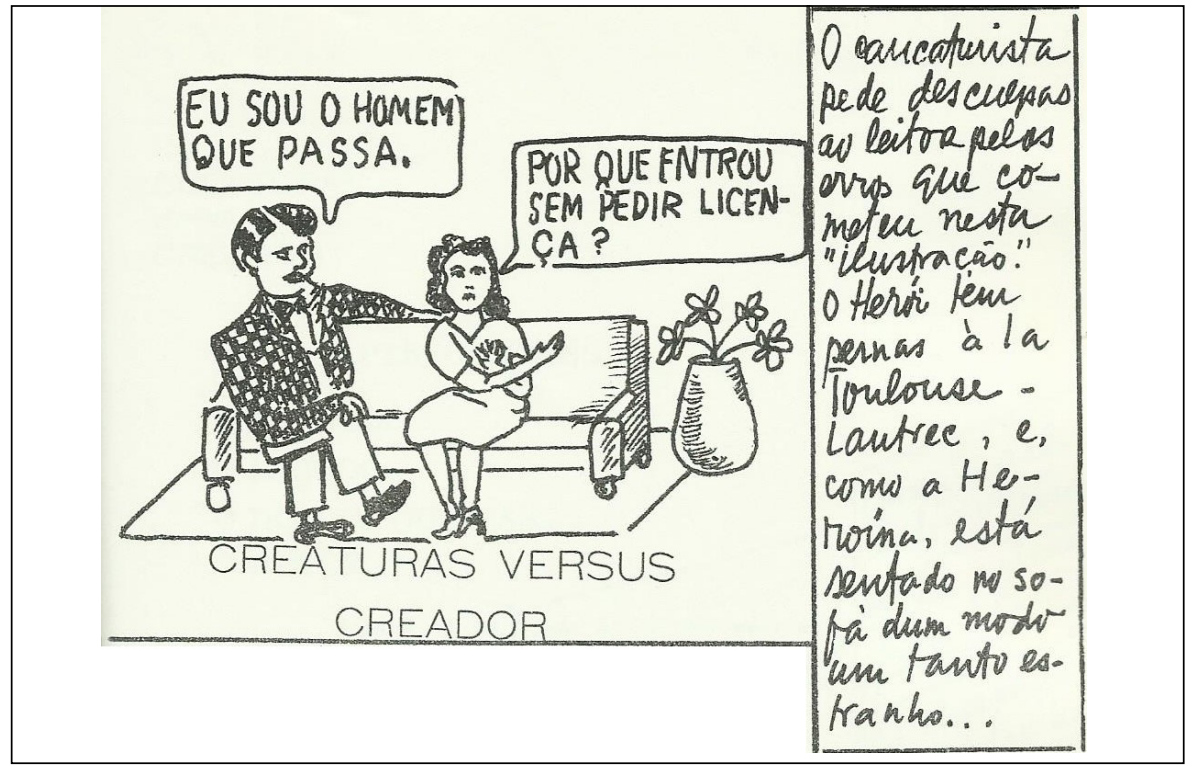

Fonte: Verissimo, 1972, p. 81. 
Percebe-se, disposto nessa figura, um homem sentado, com as pernas cruzadas, cabelo bem penteado e o braço estendido sobre o sofá no qual também está sentada uma mulher com olhar cabisbaixo e boca tortuosamente caída, que denunciam visualmente seu questionamento descontentado. Associado às disposições das personagens ilustradas encontra-se ponderações verbais feitas por Verissimo (1972, p. 81): “O caricaturista pede desculpas ao leitor pelos erros que cometeu nesta 'ilustração'. O herói tem perna à la Toulouse-Lautrec, e, como a Heroína, está sentada no sofá dum modo um tanto estranho...".

Essa complementação escrita de Verissimo é feita em terceira pessoa, o artista referindo-se a si mesmo como "o caricaturista pede desculpas ao leitor [...].". Ela também designa um esclarecimento a respeito da caricatura onde ele mesmo ratifica a falta de simetria entre os elementos desenhados. Para definir a autoavaliação de Verissimo com relação a sua produção é possível e conveniente fazer uso das palavras de Auroeut (2014, p. 42), mesmo que ele as tenha usado para seus estudos diferentes, já que os dele são voltados aos cinematográficos: "essas instruções também podem tomar a forma de avaliações."

Ademais, muitos dos registros manuscritos de Erico Verissimo denotam, de uma forma ou de outra, uma avaliação, com teor autocrítico, como na expressão "muito moderno" com relação à frase "Espicha a memória" (VERISSIMO, 1972, p. 133), do conto Faustino, conforme representado na figura abaixo:

FIGURA 4 - Desenho representativo de avaliação

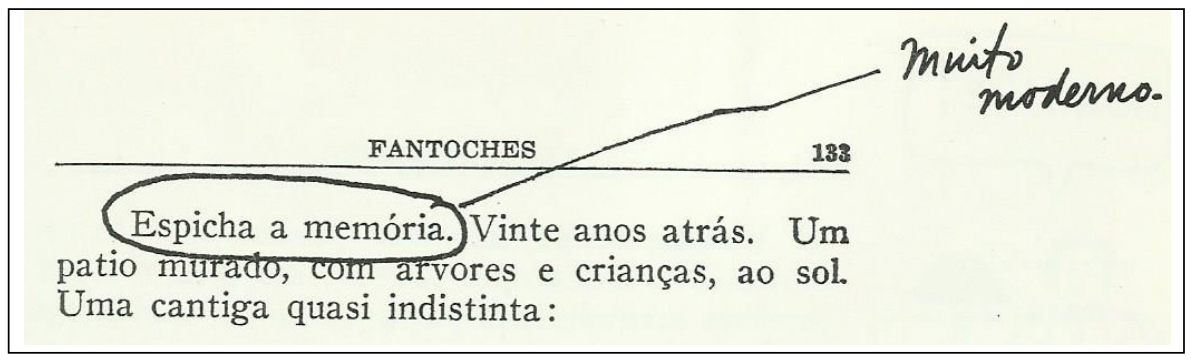

Fonte: Verissimo, 1972, p. 133.

Outrossim, o Erico Verissimo de 1932, o de 1972, os variados personagens, desenhos e manuscritos verbais de Verissimo publicados na versão de Fantoches (1972) constituem uma polifonia, presente inclusive 
no diálogo e imagem de personagens desenhados, e também com a imagem inventada do filho do pai, conforme figura a seguir:

FIGURA 5 - Desenho polifônico: o filho do pai

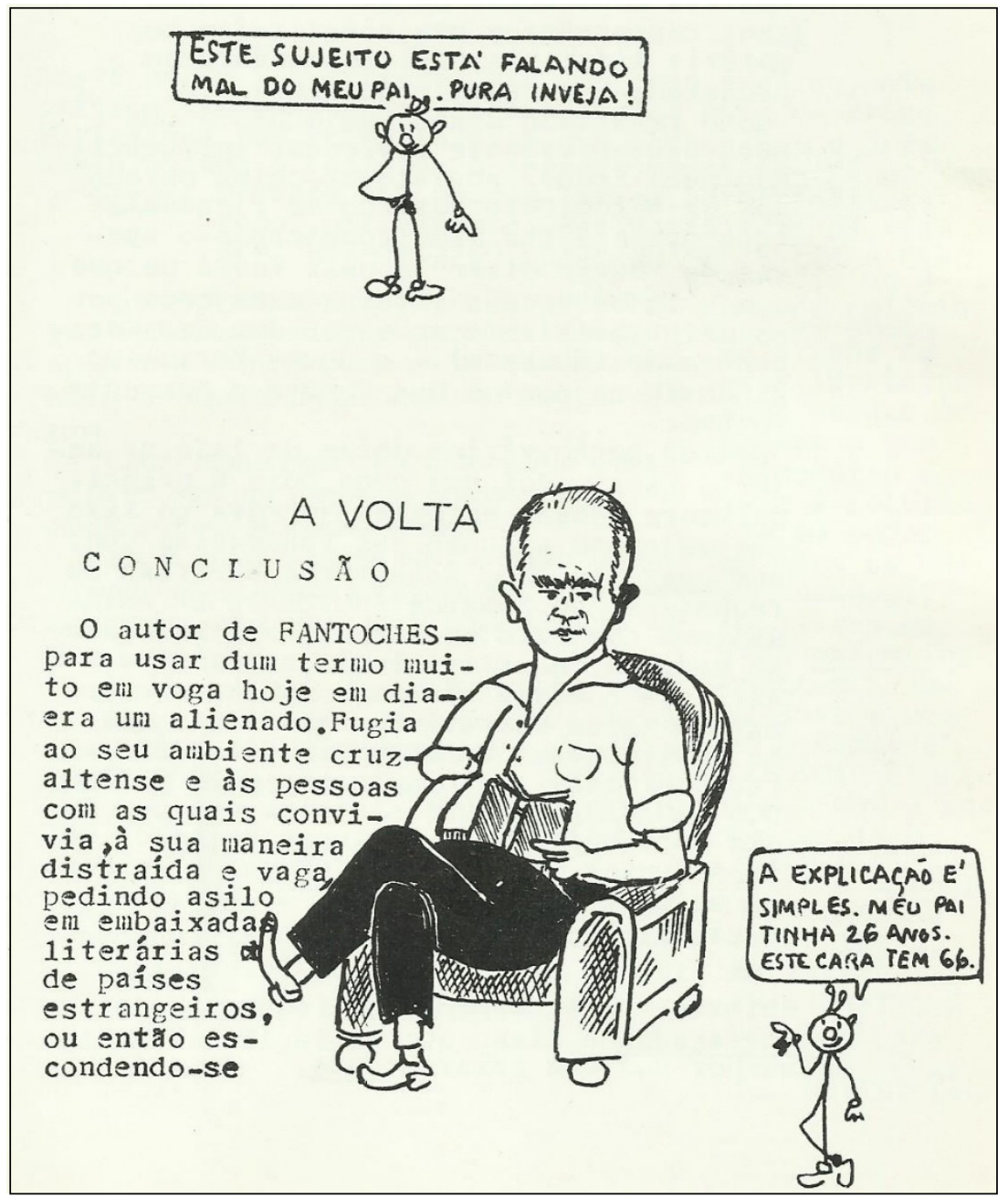

Fonte: Verissimo, 1972, p. 201.

A partir das evidências encontradas na figura acima, infere-se que, possivelmente, o "Este sujeito" mencionado pelo ser caricaturado, estilo personagem-palito, pelo menos assim aqui denominado, é o criador dele, o próprio Verissimo. Para chegar a essa afirmação, basta saber que ele nasceu 
em 1905 e Fantoches foi publicado em 1932, 27 anos de diferença, mas levando em conta que um ano não tem apenas um dia, mas sim 365 , e fazse aniversário apenas um dia do ano e se completa a idade a partir daquele dia, sendo este entre primeiro de janeiro e 31 de dezembro.

Dessa forma, ao fazer uso da matemática da subtração é possível corroborar que Erico Verissimo tinha 26 anos na publicação de Fantoches de 1932, e 66 na versão de 1972. Ainda dentro dessa lógica, vale mencionar que a versão de Fantoches de 1972 foi uma homenagem aos 40 anos da publicação da primeira versão. Seria muita coincidência, mas hipóteses e possibilidades existem, assim como inúmeras pessoas reais e personagens inventadas. Sendo assim, o personagem-palito poderia ser a voz polifônica representativa da primeira publicação da obra Fantoches, de 1932, dentro dessa matemática.

No entanto, dentro dessa hipótese, a concepção de que os dois indivíduos sobre os quais fala o personagem-palito são, na verdade, o mesmo sujeito é reforçada com a conjugação do verbo ter. O personagempalito - elemento polifônico com relação à obra publicada - usa o verbo ter conjugado na terceira pessoa do singular do pretérito imperfeito do modo indicativo (tinha) referindo-se ao sujeito com 26 anos, sujeito do passado; e na terceira pessoa do singular do presente do modo indicativo (tem) referindo-se ao sujeito com 66 anos, sujeito do presente.

Além do mais, o Verissimo com 66 anos com certeza não é mais o mesmo da época que tinha 26 anos. Durante esse tempo, o autor muito viveu e muito escreveu. No entanto, ele, com 66 anos, está distante do ano de 1932, e, com certeza, não lembra exatamente tudo que viveu e pensava naquela época. Por isso a concebível exclamação "pura inveja" exclamada pelo personagem-palito. Ou, então, inveja da mocidade. Hipótese também aceitável se for outro o senhor de 66 anos, e não Verissimo.

Enfim, muitas são as percepções possíveis a partir das marginálias de Fantoches (1972), feitas pelo próprio autor da obra. No entanto, ainda convém mencionar um manuscrito importante, disposto na figura a seguir: 
FIGURA 6 - Relação entre textos/intertextualidade

návestará aqui una
das sementes
FANTOches
de INCIDENTE
EM ANTARES?
- To be or not to be! That is the question!
That is the question! E mostrava com gestos
delirantes a caveira horrenda.
Nanquinóte sorriu com superioridade. To-
mou das mãos do outro o craneo alvo.
- Vais ver como se resolve o problema da
vida e da morte. E' a minha filosofia: nanquino-
tismo puro. Simplissimo. A caveira te apavo-
ra, te inquieta, te faz pensar? Eis a solução.

Fonte: Verissimo, 1972, p. 191.

Essa imagem permite verificar que a mentalidade do autor é um hipertexto, ou seja, é uma fonte (in)esgotada de obras interligadas. Como, por exemplo, na figura acima, pois talvez o autor não tenha percebido antes, mas ao reler sua obra e fazer contemplações na mesma, questiona-se sobre a possível relação de um trecho de Nanquinote, um dos integrantes de Fantoches, com Incidente em Antares, romance que viria a escrever anos mais tarde.

Desse modo, uma obra é resultante de informações e conhecimentos prévios do autor, de leituras e vivências. Apesar disso, é impossível uma obra conter tudo, e tal logística permite que ela seja complementada e atualizada pelos leitores, receptores dela, uma vez que o próprio Erico Verissimo era leitor daquilo que criou e realiza observações e críticas construtivas a respeito de suas criações. Tais evidências confirmam que a mente de um autor é uma rede de textos, uma agulha e uma linha de costura que perdura ao longo da vida e dos textos de um autor.

\section{Considerações finais}

As imagens e as anotações verbais não estão ali, nas marginálias de Fantoches (1972), apenas como uma forma de complementação de algo, muito menos apenas com a concepção de que Verissimo as desenhou por passatempo. Elas estão ali também para representarem o dito e o não dito 
das narrativas, seja das personagens, dos cenários, dentre outros elementos. Desse modo, o verbal e o não verbal feitos pelo próprio autor são como croquis pós-confecção, ou seja, uma roupagem feita para vestir melhor seus filhos - os personagens e as narrativas.

Diante disso, os elementos gráficos e imagéticos são complementações e, de certa forma, suporte para as obras. Esse suporte é de uma abrangência visível, pois é composta por diferentes anotações, personagens e demais seres, como o "personagem-palito" aqui considerado ao longo dos estudos. Este, junto a outras vozes manifestadas nas marginálias, bem como as vozes narrativas, constituem uma polifonia.

Em vista às análises realizadas, é possível verificar que nas marginálias de Fantoches (1972) são guardadas várias vozes, várias complementações feitas por Verissimo. Essa revisitação do autor à sua obra marca uma releitura daquilo que antes ele não havia constatado. $\mathrm{O}$ autor de outrora não era tão experiente como o de agora, ainda não havia escrito tantas obras. Afinal, sua primeira publicação foi essa que ele voltou para criticar, estabelecer relações com outras obras, acrescentar informações e vozes interacionais por meio das marginálias, que simbolizam as lacunas antes deixadas e que, 40 anos depois, foram evidenciadas.

Através dos textos, dos desenhos, das falas escritas e das caricaturas tem-se um aglomerado de processos criativos. Ao serem vistas como notas feitas por Verissimo, as marginálias de Fantoches (1972) são, em tese, uma figuração do mundo feita de pedaços de experiências, imaginações e realidades que, juntos, formam um mosaico de informações, retalhos que vestem um corpo, uma obra.

Livros e textos são fantoches que mostram o mundo de outra forma, mas cabe ao leitor fazer bom uso desses guias e intermediadores. No caso de Fantoches, o autor, também tendo sido leitor, permitiu-se fazer uma constituição de identidade de memórias através de seus manuscritos verbais e imagéticos. Autocrítico e modesto como é, Verissimo faz bastantes considerações, inclusive sobre possíveis melhorias. Afinal, assim como todo texto é inacabado, também nenhum autor é perfeito, completo; e Verissimo reconhece isso, o que engrandece ainda mais sua modéstia, a qual contribui para a composição da roupagem de suas próprias obras e personagens. 


\section{Referências}

ACKERMAN, Ada. Os desenhos preparatórios de Ivan, o Terrível, que tipo de ferramenta genética? A análise genética aplicada aos filmes. In: PASSOS, Marie-Hélène Paret et al (org.). Processo de criação Interartes: cinema, teatro e edições eletrônicas. Vinhedo: Editora Horizonte, 2014. p. 61-88.

AUROUET, Carole. Do visual ao verbal: o método de escritura do roteiro de Jacques Prévert. O exemplo de Les visiteurs du soir. In: PASSOS, MarieHélène Paret et al (org.). Processo de criação Interartes: cinema, teatro e edições eletrônicas. Vinhedo: Editora Horizonte, 2014. p. 33-59.

BORDINI, Maria da Glória. Criação literária em Erico Verissimo. Porto Alegre: L\&PM: EDIPUCRS, 1995.

VERISSIMO, Erico. Fantoches. Porto Alegre: Editora Globo, 1972.

VERISSIMO, Erico. Solo de clarineta: memórias. 20. ed. São Paulo: Companhia das Letras, 2005. v. 1.

Recebido em: 20 de abril de 2019. Aprovado em: 22 de outubro de 2019. 